\title{
The Structure and Productivity of Winter Durum Wheat Subject to Pre-Sowing Treatment
}

\author{
Podlesnykh Nadezhda \\ Dept. of Crop Science, Forage Production and Agricultural \\ Technologies \\ Voronezh State Agrarian University named after Emperor \\ Peter the Great Voronezh, Russia \\ Env.05@mail.ru
}

\begin{abstract}
The paper studies the productivity of winter durum wheat of Zolotko variety subject to the treatment of seed grains with the preparations Poly-Feed, Plodorodiye Sibiri, Vitazim, Agat-25K, Micromak, potassium humate applied separately and in the mixture of Poly-Feed + Plodorodiye Sibiri + Vitazim followed by the treatment of plants with Vitazim, Fertigrain Foliar and the mixture of Vitazim + Fertigrain Foliar in the forest-steppe of the Central Chernozem Region. The experiments were conducted in 2014/15-2015/16 in the fields of Voronezh SAU. For the treatment of winter durum wheat seeds, the most effective preparations to increase tillering capacity were Agat-25K (1.18 seeds/plant), Vitazim (1.17 seeds/plant) and potassium humate (1.17 seeds/plant). The number of kernels per head increased provided that the seeds were treated with Agat25K, Micromak, Plodorodiye Sibiri, especially followed by the further treatment of plants with the mixture of Vitazim + Fertigrain Foliar. The weight of grains in the ear increased up to 1.28 and $1.27 \mathrm{~g}$ when the seeds were treated with Agat-25K and Micromak jointly with the treatment of plants with Vitazim + Fertigran Foliar. A thousand grain weight was greater when the seeds were treated with Agat 25K, Micromak and potassium humate jointly with the treatment of plants with a mixture of Vitazim + Fertigrean Foliar and amounted to $45.0 ; 44.9$ and 44.85g, respectively. A high yield was obtained when Agat-25K and Micromak were used for treating seeds, together with treating plants with a mixture of Vitazim + Fertigrean Foliar. It amounted to 52.7 and $52.2 \mathrm{c} / \mathrm{ha}$, respectively. The highest synergetic efficiency was observed when treating the seeds with Agat-25K or Micromak together with treating the plants with Vitazim + Fertigrain Foliar mixture.
\end{abstract}

Keywords - winter durum wheat, pre-sowing treatment, foliar treatment, tillering capacity, number of kernels per head, weight of grains in the ear, thousand grain weight, yield, synergetic effect.

\section{INTRODUCTION}

Grain is the most important strategic product that determines the stable functioning of the agricultural market and the food security of the country. The Central Black Earth Region is one of the main producers of food and feed grains. In the conditions of the Central Black Earth Region, winter wheat prevails, occupying at least $20-25 \%$ of arable land (1-3, $8,17)$. Yet, the production of durum wheat that is necessary for pasta manufacturers is extremely insufficient, since recognized spring durum varieties are much less productive. Today, there is an opportunity to advance durum wheat

\author{
Galochkina Nadezhda \\ Dept. of Merchandising and Expert Examination of Goods \\ Voronezh State Agrarian University named after Emperor \\ Peter the Great Voronezh, Russia \\ Galochkina.na@mail.ru
}

production through the application of winter varieties of this crop.

The authors studied the impact of bioactive substances and bacterial preparations on the winter durum wheat productivity, which are still little studied. In this regard, the impact of presowing treatment and the one applied to vegetative plants with growth-regulating preparations is currently relevant (3-7, 916).

\section{MATERIALS AND METHODS}

The experiments with winter durum wheat of Zolotko variety were carried out in the fields of the Voronezh State Agrarian University in 2014/15-2015/16, following a twofactor scheme:

Factor A - pre-sowing treatment. Seven types for presowing treatment at the stem elongation stage were investigated: Poly-Feed 19-19-19 (1.5 kg/t), Plodorodiye Sibiri $(2.51 / \mathrm{t})$, Vitazim (1 1/t), Agat-25K (0.04 1/t ), Micromak (2 1/t), potassium humate $(0.3 \mathrm{l} / \mathrm{t})$, mixture (Poly-Feed - $1 \mathrm{~kg} / \mathrm{t}$ + Plodorodiye Sibiri - $2 \mathrm{l} / \mathrm{t}+$ Vitazim - $0.5 \mathrm{l} / \mathrm{t}$ ) and control value 1 (without pre-sowing treatment).

Factor B - foliar treatment. Three types for treatment at the stem elongation stage were investigated: Vitazim ( 1 l/ha), Fertigran Foliar (1 1/ha), Vitazim (1 1/ha) + Fertigrain Foliar (1 $1 /$ ha) and control value 2 (without treatment of plants).

The soils from the experimental plot are represented by leached middle loamy chernozem. The record plot is $20 \mathrm{~m}^{2}$, the location of plots is systematic and the replication of experiment is four times.

Winter durum wheat of the Zolotko variety was sown out to a depth of $4-5 \mathrm{~cm}$ in an ordinary manner with a seed rate of 5 million seeds/ha in black fallow land within optimum time frame.

The wheat seeds were treated in advance with Vincit Forte at a dose of $11 / \mathrm{t}$ in all types of the experiment, including control assessment, and before sowing they were treated with one of the studied preparations (factor A):

Poly-Feed 19-19-19, a complex water-soluble non-chlorine fertilizer of a new generation, a nutrient complex. It consists of nitrogen, phosphorus, potassium, trace elements, as well as growth biostimulant and bioprotector MAR known as a plant 
complex of seaweed extract that stimulates metabolic processes of plants, increases immunity and creates a barrier against disease. It is used to stimulate germination and seed sprouting energy, to promote the rapid development of the root system, and to build plant resilience to diseases and adverse weather conditions (dose in the experiment $-1.5 \mathrm{~kg} / \mathrm{t}$ ).

Peat-gel Plodorodiye Sibiri, a humic preparation of a new generation with a high content of biologically active substances, balanced as per the content of natural micro-and macronutrients in a mobile form (dose in the experiment -2.5 $\mathrm{kg} / \mathrm{t}$ ).

Vitazim, a natural, non-toxic multi-profile biostimulant. It activates the process of photosynthesis, improves the symbiosis of soil microorganisms with plants, and contributes to the increase in stress resistance (dose in the experiment $1.0 \mathrm{l} / \mathrm{t})$.

Agat-25K, a biological fungicidal and growth-promoting preparation $(18 \mathrm{mg} / \mathrm{kg}$ of 3-indolylacetic acid $+60 \mathrm{mg} / \mathrm{kg}$ of aalanine $+70 \mathrm{mg} / \mathrm{kg}$ of a-glutamic acid). Agat-25K improves germination rate, productive tillering capacity and disease resilience. It promotes increased yields and crop quality (dose in the experiment $-0,04 \mathrm{~kg} / \mathrm{t}$ ).

Micromak, a liquid complex microfertilizer for seed treatment. It contains 12 micro and 5 macronutrients, accelerates sprouting, increases germination rate, tillering productive capacity and yield gain (dose in the experiment -2 $1 / \mathrm{t})$.

Potassium humate, a natural plant growth stimulator based on humic acid salts. It increases germination energy and seed sprouting, strengthens the immune system of plants, stimulates the development of an extensive root system, promotes active nutrient supply, provides plant nutrition with microelements, intensifies metabolic processes in a plant cell, and provides yield gain (dose in the experiment $-0.3 \mathrm{l} / \mathrm{t}$ ).

Fertigrain Foliar, a leaf biostimulant that facilitates the vegetative development of plants; promotes better grain ripening; increases ear-grain content; builds stress resistance; improves productivity and yielding capacity; eliminates micronutrient deficiencies. The composition is 5\% nitrogen, $40 \%$ organic matter, $0.75 \%$ zinc, $0.5 \%$ manganese, $0.1 \%$ copper, $0.1 \%$ boron, $0.1 \%$ iron, $0.02 \%$ molybdenum, $0.01 \%$ cobalt, $8 \%$ free $\mathrm{L}$ amino acids (dose in the experiment $-11 / \mathrm{t}$ ) $(3,17-19)$.

To provide soil fertility the following operations were performed, namely: early-spring fertilization with ammonium nitrate $(35 \mathrm{~kg} \mathrm{r.a./ha})$; at the stem elongation stage - foliar feeding with carbonyl diamide (20 kg r.a./ha); pesticidal treatment - when needed (herbicide Caliber - $40 \mathrm{~g} / \mathrm{ha}+$ potassium humate Sufler - $0.3 \mathrm{l} / \mathrm{ha}$; insecticide Decis Profi $40 \mathrm{~g} / \mathrm{ha}$; fungicide Titus Duo - $0.32 \mathrm{l} / \mathrm{ha}$ ).

The treatment of plants with the studied preparations (factor B) was carried out as soon as the flag leaf emerged or at the heading stage manually with a knapsack sprayer for all seed treatment types within the experiment.
The wheat was harvested plot by plot by the SR 2010 "Terrion Sampo" selection harvester. The bunker grain yield was calculated for $100 \%$ purity and $14 \%$ moisture.

\section{CONCLUSIONS}

Productivity attributes such as tillering capacity, the number of kernels per head, the weight of grains in the ear, thousand grain weight impacted by biologically active preparations were determined on the basis of appropriate methods adopted in GOSSORTSET $(20,21)$.

\section{TABLE I. TILLERING CAPACITY AND NUMBER OF KERNELS PER HEAD IN WINTER DURUM WHEAT SUBJECT TO THE TREATMENT OF SEEDS AND PLANTS, AVERAGE FOR 2015 - 2016}

\begin{tabular}{|c|c|c|c|c|c|c|c|c|c|c|}
\hline \multirow[b]{3}{*}{ 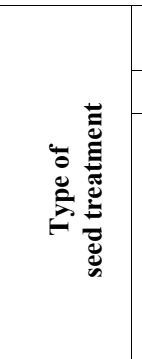 } & \multicolumn{5}{|c|}{$\begin{array}{c}\text { Tillering capacity, } \\
\text { seeds/plant }\end{array}$} & \multicolumn{5}{|c|}{$\begin{array}{c}\text { Number of kernels per } \\
\text { head, seeds }\end{array}$} \\
\hline & \multicolumn{10}{|c|}{ Type of plant treatment } \\
\hline & $\begin{array}{l}\frac{N}{0} \\
\stackrel{0}{0} \\
0\end{array}$ & $\begin{array}{l}\text { 罵 } \\
\stackrel{5}{5}\end{array}$ & 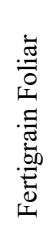 & 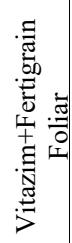 & 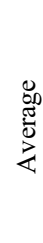 & $\begin{array}{l}\text { D } \\
\text { 咅 } \\
\text { e }\end{array}$ & 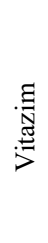 & 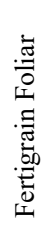 & 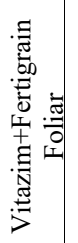 & \\
\hline 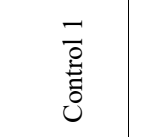 & $\stackrel{n}{2}$ & $\stackrel{8}{\circ}$ & $\stackrel{8}{\circ}$ & $\stackrel{\leftrightarrow}{\stackrel{-}{-}}$ & $\stackrel{8}{\circ}$ & $\begin{array}{l}\stackrel{\cap}{+} \\
\stackrel{+}{d}\end{array}$ & 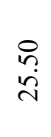 & $\begin{array}{l}8 \\
\dot{i} \\
\text { in }\end{array}$ & 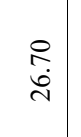 & $\begin{array}{l}\infty \\
n \\
n\end{array}$ \\
\hline 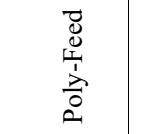 & $\stackrel{n}{=}$ & $\stackrel{n}{=}$ & $\stackrel{n}{=}$ & $\stackrel{\because}{\rightleftarrows}$ & $\stackrel{?}{=}$ & $\frac{n}{2}$ & 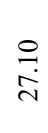 & 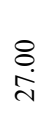 & $\frac{\curvearrowright}{\grave{n}}$ & \\
\hline 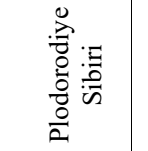 & $\stackrel{n}{=}$ & $\stackrel{\Xi}{ت}$ & 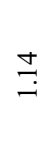 & $\stackrel{n}{\rightleftarrows}$ & $\stackrel{n}{=}$ & $\frac{n}{2}$ & \&. & 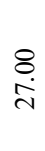 & $\begin{array}{l}8 \\
\infty \\
\infty \\
i\end{array}$ & $\stackrel{?}{\sigma}$ \\
\hline$\stackrel{\text { : }}{\stackrel{\Xi}{\leftrightarrows}}$ & $\cong$ & $\stackrel{0}{=}$ & $=$ & $\exists$ & $=$ & $\begin{array}{l}\stackrel{0}{2} \\
\stackrel{n}{i}\end{array}$ & ஓ. & $\stackrel{n}{\stackrel{n}{c}}$ & $\begin{array}{l}\infty \\
\stackrel{\sim}{\sim} \\
\stackrel{\sim}{N}\end{array}$ & \\
\hline 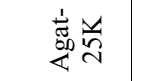 & $\stackrel{\infty}{=}$ & $\stackrel{\infty}{=}$ & $\stackrel{9}{=}$ & $\stackrel{\infty}{=}$ & $\stackrel{\infty}{=}$ & $\begin{array}{l}\text { ป̂ } \\
\text { ปे }\end{array}$ & $\begin{array}{l}\stackrel{2}{0} \\
\text { iे }\end{array}$ & $\begin{array}{l}\mathfrak{n} \\
\stackrel{i}{0}\end{array}$ & 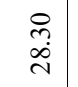 & $\begin{array}{l}\infty \\
\infty \\
\dot{0} \\
0\end{array}$ \\
\hline 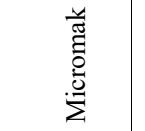 & $\Xi$ & $\Xi$ & 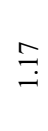 & $\Xi$ & 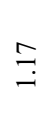 & $\begin{array}{l}\text { ते } \\
\text { in }\end{array}$ & $\begin{array}{l}\text { i. } \\
\text { i. }\end{array}$ & 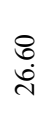 & $\underset{\substack{0 \\
\infty}}{\stackrel{\infty}{\sim}}$ & $\begin{array}{l}6 \\
\dot{0} \\
\text { N. }\end{array}$ \\
\hline 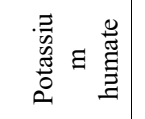 & $\stackrel{n}{=}$ & $\stackrel{\sim}{=}$ & $\begin{array}{l}= \\
=\end{array}$ & $\begin{array}{l}0 \\
\stackrel{1}{=}\end{array}$ & $\stackrel{0}{=}$ & $\begin{array}{l}\stackrel{0}{1} \\
\text { in }\end{array}$ & $\underset{\substack{n \\
\delta}}{\stackrel{v}{\delta}}$ & 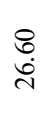 & $\stackrel{?}{\stackrel{i}{i}}$ & ?ّ \\
\hline 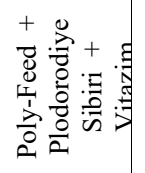 & $\exists$ & $\stackrel{\Xi}{ت}$ & $\stackrel{ \pm}{ت}$ & $\rightleftarrows$ & $\underset{\Xi}{\Xi}$ & $\begin{array}{l}\text { ते } \\
\text { ปे }\end{array}$ & in & $\stackrel{\text { i }}{\stackrel{9}{\circ}}$ & 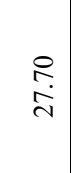 & 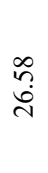 \\
\hline
\end{tabular}


In our studies, tillering capacity of winter durum wheat partly varied subject to the treatment of seeds and plants with the studied preparations (Table 1).

Over the two years of research, pre-sowing treatment on average had a positive effect on the increase in tillering capacity in all types of the experiment (by 0.09-0.13 seeds/plant or $8.6-12.4 \%$ ). Agat-25K, as well as Vitazim and Micromak, turned out to be the best seed treatment preparations.

A relatively late treatment of winter wheat plants did not affect the tillering capacity.

The number of kernels per head increased both resulting from pre-sowing treatment and from spraying winter durum wheat plants with the studied preparations. The pre-sowing seed treatment slightly increased this indicator (by $0.6-0.75$ seeds). The foliar dressing increased the number of kernels per head by 1.0-2.2 seeds or 4.1-9.0\%. A greater number of kernels per head was observed with the combined use of presowing and foliar treatments. The best types of seed treatment were provided by Agat-25K, Micromak, Plodorodiye Sibiri together with the foliar treatment by the mixture of Vitazim + Fertigrain Foliar. By the control time the gain was 3.8, 3.6, 3.5 kernels per head or $15.5,14.7$, and $14.3 \%$, respectively.

Subject to the treatment of seeds and plants with the studied preparation, the average weight of grains in the ear also changed (Table 2).

Over the years of research, the average weight of grains in the ear increased when the seed grains were treated with biopreparations by $0.04-0.05 \mathrm{~g}$ or $3.8-4.8 \%$ as compared with the control value for all studied types.

The foliar treatment with the studied preparations (especially Vitazim + Fertigrain Foliar) effectively influenced the average weight of grains in the ear, increasing it by 0.05 $0.12 \mathrm{~g}$ or $4.8-11.5 \%$. The best indicators were obtained when the foliage spraying with the preparation was provided.

The combined treatment of seeds and plants significantly increased the weight of grains in the ear. The ears were heavier with the seeds being treated with Agat-25K and Micromak combined with the treatment of plants with a mixture of Vitazim + Fertigrain Foliar. In these cases, the weight of grains in the ear was 1.28 and $1.27 \mathrm{~g}$.

The thousand grain weight varied from 42.2 to $45.0 \mathrm{~g}$, depending on the treatment with biopreparations. The presowing treatment increased the weight of 1000 grains slightly - by $0.45-0.90 \mathrm{~g}$ or $1.6-2.1 \%$. The best result $(43.15 \mathrm{~g})$ was obtained by treating the seeds with Agat-25K.

The thousand grain weight increased more significantly after the treatment of plants. In the best type, when using the mixture of Vitazim + Fertigrain Foliaron it was $43.4 \mathrm{~g}$, which was $1.15 \mathrm{~g}$ or $2.7 \%$ more compared to the control value.
TABLE II. AVERAGE WEIGHT OF GRAINS IN THE EAR AND THOUSAND GRAIN WEIGHT OF WINTER DURUM WHEAT SUBJECT TO THE TREATMENT OF SEEDS AND PLANTS, AVERAGE FOR 2015-2016

\begin{tabular}{|c|c|c|c|c|c|c|c|c|c|c|}
\hline \multirow[b]{3}{*}{ 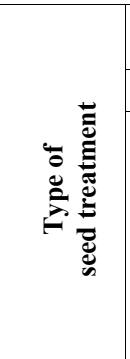 } & \multicolumn{5}{|c|}{$\begin{array}{c}\text { Average weight of grains in } \\
\text { the ear, } g\end{array}$} & \multicolumn{5}{|c|}{ Thousand grain weight, $\mathrm{g}$} \\
\hline & \multicolumn{10}{|c|}{ Type of plant treatment } \\
\hline & $\begin{array}{l}\frac{1}{0} \\
\stackrel{0}{0} \\
0\end{array}$ & 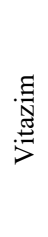 & 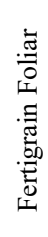 & 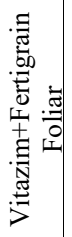 & 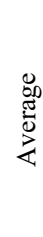 & 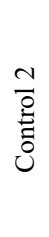 & 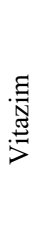 & 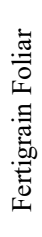 & 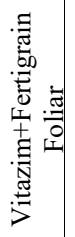 & 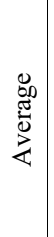 \\
\hline $\begin{array}{l}\overline{0} \\
\text { : } \\
\text { ठ }\end{array}$ & $\stackrel{t}{0}$ & $\stackrel{8}{0}$ & $\hat{o}$ & $\stackrel{0}{=}$ & 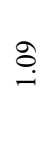 & 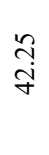 & 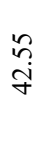 & $\begin{array}{l}\stackrel{4}{i} \\
\stackrel{4}{i}\end{array}$ & $\stackrel{q}{\stackrel{q}{q}}$ & $\begin{array}{l}\stackrel{4}{i} \\
\stackrel{4}{i}\end{array}$ \\
\hline 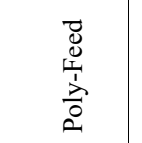 & $\stackrel{\infty}{\stackrel{\infty}{-}}$ & $\stackrel{9}{\stackrel{9}{\rightleftarrows}}$ & $\stackrel{\infty}{=}$ & $\stackrel{n}{\dddot{c}}$ & 三 & 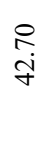 & $\stackrel{r}{r}$ & 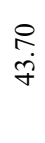 & $\stackrel{n}{n}$ & $\begin{array}{l}: \\
\stackrel{\leftrightarrow}{+} \\
\dot{f}\end{array}$ \\
\hline 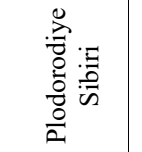 & $\stackrel{\infty}{\circ}$ & $\stackrel{\infty}{=}$ & $\stackrel{\infty}{=}$ & $\stackrel{\overbrace{}}{\dddot{c}}$ & $\Xi$ & 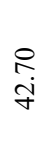 & $\begin{array}{l}n \\
\tilde{f} \\
\tilde{f}\end{array}$ & $\begin{array}{l}\because \\
\tilde{q} \\
\tilde{q}\end{array}$ & $\begin{array}{l}\stackrel{8}{8} \\
\dot{7}+\end{array}$ & $\begin{array}{l}n \\
\tilde{f} \\
\dot{f}\end{array}$ \\
\hline 䔍 & $\stackrel{\infty}{\circ}$ & $\stackrel{9}{\stackrel{9}{\rightleftarrows}}$ & $\stackrel{\infty}{=}$ & $\cong$ & 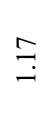 & $\begin{array}{l}\stackrel{8}{ } \\
\text { f }\end{array}$ & $\begin{array}{l}2 \\
\stackrel{f}{f} \\
\dot{f}\end{array}$ & $\begin{array}{l}\stackrel{ }{\dot{f}} \\
\underset{f}{+}\end{array}$ & $\begin{array}{l}n \\
\mathfrak{z} \\
\dot{y}\end{array}$ & $\begin{array}{l}\stackrel{一}{f} \\
\dot{f}\end{array}$ \\
\hline 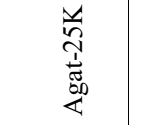 & $\stackrel{g}{-}$ & $\stackrel{\text { ঙ̊ }}{\rightarrow}$ & $\stackrel{\widetilde{Y}}{\sim}$ & $\stackrel{\infty}{\stackrel{\infty}{\longrightarrow}}$ & $\stackrel{9}{=}$ & $\stackrel{n}{\stackrel{n}{q}}$ & $\begin{array}{l}\stackrel{9}{+} \\
\text { j }\end{array}$ & 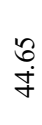 & $\underset{ }{8}$ & $\begin{array}{l}\stackrel{n}{n} \\
\dot{f}\end{array}$ \\
\hline 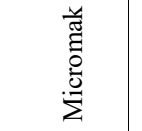 & $\stackrel{\infty}{\circ}$ & $\stackrel{\infty}{=}$ & $\stackrel{\vartheta}{=}$ & $\hat{\Upsilon ָ}$ & $\stackrel{\infty}{=}$ & $\begin{array}{l}\mathscr{\infty} \\
\infty \\
\stackrel{y}{+}\end{array}$ & $\begin{array}{l}\stackrel{\imath}{\sim} \\
\dot{f}\end{array}$ & $\begin{array}{l}\stackrel{n}{f} \\
\dot{f}\end{array}$ & $\begin{array}{l}\stackrel{8}{\&} \\
\dot{+}\end{array}$ & $\begin{array}{l}\exists \\
\exists \\
\dot{y}\end{array}$ \\
\hline 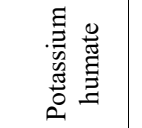 & $\stackrel{\infty}{\circ}$ & $\stackrel{\infty}{=}$ & $\stackrel{\infty}{=}$ & $\stackrel{\overbrace{}}{\dddot{c}}$ & $=$ & $\begin{array}{l}\infty \\
\infty \\
\text { i }\end{array}$ & $\begin{array}{l}8 \\
\dot{f}\end{array}$ & $\begin{array}{l}\stackrel{ }{\div} \\
\stackrel{+}{f}\end{array}$ & $\begin{array}{l}\infty \\
\infty \\
\dot{+}\end{array}$ & $\begin{array}{l}\text { मे } \\
\dot{y}\end{array}$ \\
\hline 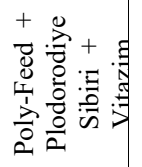 & $\stackrel{\infty}{\infty}$ & $\cong$ & 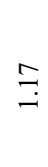 & $\stackrel{\underset{J}{c}}{\longrightarrow}$ & $\stackrel{0}{=}$ & $\begin{array}{l}\mathscr{\infty} \\
\stackrel{\mathcal{T}}{+}\end{array}$ & 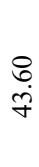 & $\begin{array}{l}\infty \\
\dot{\gamma}\end{array}$ & $\begin{array}{l}\stackrel{?}{+} \\
\stackrel{+}{+}\end{array}$ & 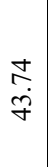 \\
\hline
\end{tabular}


TABLE III. YIELD OF WINTER DURUM WHEAT SUBJECT TO SEED AND PLANT TREATENT WITH GROTH-REGULATING PREPARATIONS FOR 2015-2016, $\mathrm{C} / \mathrm{HA}$

\begin{tabular}{|c|c|c|c|c|c|c|c|c|c|c|c|c|}
\hline \multirow[b]{3}{*}{ 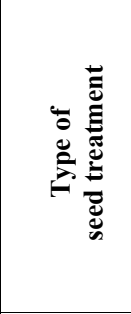 } & \multicolumn{12}{|c|}{ Type of plant treatment } \\
\hline & \multicolumn{4}{|c|}{2015} & \multicolumn{4}{|c|}{2016} & \multicolumn{4}{|c|}{ Average for 2 years } \\
\hline & $\begin{array}{l}\frac{0}{0} \\
\stackrel{\Xi}{0}\end{array}$ & 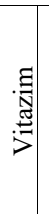 & 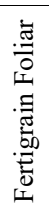 & 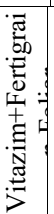 & $\begin{array}{l}\frac{N}{0} \\
\stackrel{\Xi}{0}\end{array}$ & 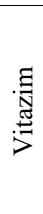 & 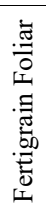 & 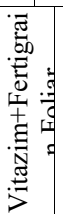 & $\frac{7}{0}$ & 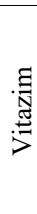 & 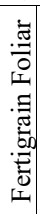 & 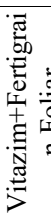 \\
\hline 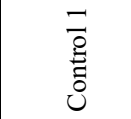 & $\vec{n}$ & ले & $\stackrel{+}{\dot{m}}$ & $\begin{array}{l}0 \\
\dot{j} \\
\dot{f}\end{array}$ & $\stackrel{n}{m}$ & $\stackrel{n}{m}$ & 㐫 & $\begin{array}{l}0 \\
\stackrel{\mathrm{i}}{\mathrm{f}}\end{array}$ & $\stackrel{?}{m}$ & 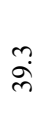 & $\begin{array}{l}\stackrel{0}{.} \\
\dot{m}\end{array}$ & ؟ \\
\hline 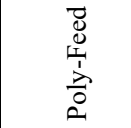 & $\underset{\infty}{\infty}$ & $\underset{f}{+}$ & $\stackrel{\circ}{\stackrel{+}{f}}$ & $\begin{array}{l}n \\
\dot{q}\end{array}$ & $\hat{\dot{q}}$ & $\stackrel{+}{\stackrel{f}{f}}$ & $\stackrel{\infty}{\underset{f}{f}}$ & $\begin{array}{l}\stackrel{g}{q} \\
\stackrel{q}{*}\end{array}$ & ণे. & $\stackrel{*}{\stackrel{*}{+}}$ & $\begin{array}{l}* \\
\stackrel{*}{f} \\
\dot{f}\end{array}$ & 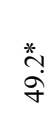 \\
\hline 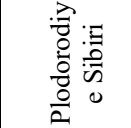 & $\vec{\infty}$ & $\begin{array}{l}\circ \\
\dot{f}\end{array}$ & $\stackrel{?}{f}$ & $\tilde{q}$ & $\stackrel{?}{\vec{F}}$ & $\overrightarrow{\dot{\gamma}}$ & $\begin{array}{l}\circ \\
\stackrel{f}{f}\end{array}$ & $\hat{g}$ & ळे & $\begin{array}{l}* \\
\infty \\
\stackrel{\sigma}{\sigma}\end{array}$ & $\begin{array}{l}* \\
\stackrel{f}{f} \\
\dot{f}\end{array}$ & $\stackrel{*}{*} \stackrel{0}{g}$ \\
\hline 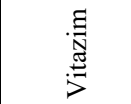 & $\stackrel{\circ}{\dot{m}}$ & $\begin{array}{c}0 \\
\dot{y} \\
\dot{f}\end{array}$ & 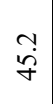 & $\begin{array}{l}\infty \\
\stackrel{0}{0} \\
\dot{n}\end{array}$ & 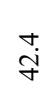 & $\stackrel{0}{i}$ & $\vec{y}$ & $\begin{array}{l}0 \\
\dot{8} \\
i n\end{array}$ & $\hat{\dot{q}}$ & $\begin{array}{l}* \\
\dot{y} \\
\dot{q}\end{array}$ & $\begin{array}{c}* \\
\vec{v} \\
\dot{v}\end{array}$ & $\stackrel{*}{*}$ \\
\hline 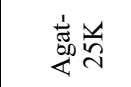 & $\stackrel{\infty}{\stackrel{+}{+}}$ & $\hat{⿱ 亠 䒑}$ & $\begin{array}{c}a \\
\infty \\
\infty\end{array}$ & $\stackrel{\vec{n}}{\grave{n}}$ & $\begin{array}{l}\dot{\sigma} \\
\dot{\gamma}\end{array}$ & $\begin{array}{l}\circ \\
\dot{\varphi}\end{array}$ & $\begin{array}{l}0 \\
\dot{\sigma}\end{array}$ & $\begin{array}{l}0 \\
i \\
i\end{array}$ & $\stackrel{\text { ִָ }}{\mathcal{f}}$ & $\stackrel{*}{\stackrel{*}{f}}$ & 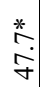 & $\stackrel{*}{\stackrel{*}{i}}$ \\
\hline 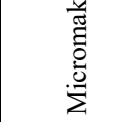 & $\hat{\dot{q}}$ & $\begin{array}{c}\stackrel{\sigma}{0} \\
\dot{0}\end{array}$ & $\begin{array}{c}\stackrel{\dot{q}}{q} \\
\stackrel{9}{*}\end{array}$ & $\begin{array}{l}n \\
\tilde{n} \\
0\end{array}$ & $\stackrel{\infty}{\underset{f}{f}}$ & $\stackrel{g}{\dot{J}}$ & 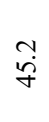 & $\stackrel{0}{\vec{n}}$ & $\stackrel{\infty}{\vec{f}}$ & 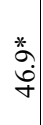 & $\underset{⿱ ⺌}{\stackrel{*}{f}}$ & $\stackrel{*}{\text { * }}$ î \\
\hline 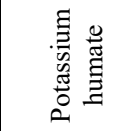 & $\stackrel{\infty}{\stackrel{q}{+}}$ & $\begin{array}{l}0 \\
\dot{\infty} \\
\dot{q}\end{array}$ & $\begin{array}{c}\infty \\
\infty \\
\dot{b}\end{array}$ & $\stackrel{m}{\stackrel{n}{n}}$ & $\stackrel{?}{F}$ & $\stackrel{n}{q}$ & $\tilde{r}$ & $\begin{array}{c}r \\
\infty \\
\infty \\
+\end{array}$ & $\stackrel{\circ}{\dot{\forall}}$ & $\begin{array}{l}* \\
0 \\
\dot{b} \\
\dot{t}\end{array}$ & $\begin{array}{l}* \\
\stackrel{*}{0} \\
\dot{\varphi}\end{array}$ & $\stackrel{*}{\stackrel{*}{8}}$ \\
\hline 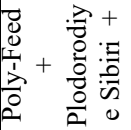 & $\underset{\infty}{\infty}$ & $\stackrel{?}{f}$ & $\stackrel{⿰}{+}$ & $\begin{array}{l}0 \\
\dot{q} \\
\dot{q}\end{array}$ & ?n & 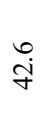 & $\overrightarrow{\dot{f}}$ & $\begin{array}{c}1 \\
\infty \\
\infty \\
\dot{q}\end{array}$ & $\vec{\infty}$ & $\begin{array}{l}\stackrel{*}{+} \\
\stackrel{\sigma}{\sigma}\end{array}$ & 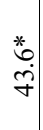 & $\begin{array}{l}* \\
\stackrel{*}{\infty}\end{array}$ \\
\hline$\dot{0}^{\circ}$ & & & & & & & & & & & & \\
\hline
\end{tabular}

a. Note: The * symbol indicates the types in which the joint use of preparations to treat seeds and plant provides a significantly increased impact (synergetic effect).

Subject to the seed treatment with Agat-25K, Micromak and potassium humate in combination with the treatment of plants with Vitazim + Fertigrain Foliarmass the thousand grain weight was much larger and amounted to 45.0, 44.9 and 44.85, respectively.
The yield of winter durum wheat varied greatly depending on the treatment of seeds and plants (Table 3).

In 2015, higher grain yields were obtained when treating the seeds with Micromak (40.9 c/ha), Agat-25K (40.8 c/ha), and potassium humate $(40.8 \mathrm{c} / \mathrm{ha})$, which exceeded the control value by $3.8,3.7$ and $3.7 \mathrm{c} /$ ha $(10.2,10.0$ and $10, \%)$, respectively. The use of other preparations provided an increase of 0.9-1.9 $\mathrm{c} / \mathrm{ha}$. When treating the plants alone (without seed treatment - control value 1), the mixture of Vitazim + Fertigrain Foliar (increase to control value 2.0 - 5.5 $\mathrm{t} / \mathrm{ha}$ ) had a greater positive effect.

The highest yield was observed in the type when the seeds were treated with Micromak in combination with the treatment of plants with Vitazim + Fertigrain Foliar. It was $53.5 \mathrm{c} / \mathrm{ha}$. Agat-25K and potassium humate in combination with the same treatment of plants were also effective and increased the yield to 53.4 and $53.3 \mathrm{c} /$ ha, respectively.

In 2016, there was also a tendency to increase the yield from the use of biopreparations for seed and plant treatment. For the pre-sowing treatment (without treatment of plants), Agat-25K was the best preparation (the increase to control value 1 was $6.1 \mathrm{c} / \mathrm{ha}$ ). The seed treatment with other studied preparations was less effective (the increase was from 2.0 to $5.3 \mathrm{c} / \mathrm{ha})$

In the type with no seed treatment, the high yield of winter durum wheat was observed when the plants were treated with the mixture of Vitazim + Fertigrain Foliar (as in 2015) and amounted to $42.6 \mathrm{c} / \mathrm{ha}$.

The high yield was obtained when the seeds were treated with Agat-25K combined with the treatment of plants with Vitazim + Fertigrain Foliar. It was $52.0 \mathrm{c} / \mathrm{ha}$. The use of Micromak and Vitazim for pre-sowing treatment together with the treatment of plants with the same preparations also led to high yields -51.0 and $50.6 \mathrm{c} / \mathrm{ha}$, respectively.

Over the two years, the best yield results on average were obtained when the seeds were treated with Agat-25K and Micromak (an increase of control value was 4.9 and $4.5 \mathrm{c} / \mathrm{ha}$ ). Treating plants was most effective when using Vitazim + Fertigrain Foliar.

The combined use of preparations to treat the seeds and plants was effective, to one degree or another, in all types. A higher yield was obtained when Agat-25K and Micromak were used for treating seeds in combination with plant treatment with Vitazim + Fertigrain Foliar. It was 52.7 and $52.2 \mathrm{c} /$ ha, respectively. In these types, the yield increase from the complex treatment of seeds and plants of winter durum wheat was 15.4 and $14.9 \mathrm{c} / \mathrm{ha}$ of grain. The sum of yield gains from the separate use of the same preparations turned out to be significantly less -10.2 and $9.8 \mathrm{c} / \mathrm{ha}$.

In this case, the synergetic effect from the interaction of preparations used in the treatment of seeds and plants was 5.2 and $5.1 \mathrm{c} /$ ha. Synergism manifested itself in other types, although to a lesser extent (Table 4). 
TABLE IV. YIELD GAIN RESULTED FROM SINERGISM* WHEN APPLYING COMBINED PREPARATIONS FOR WINTER DURUM WHEAT (SEEDS AND PLANTS), AVERAGE FOR 2015-2016, C/HA

\begin{tabular}{|c|c|c|c|}
\hline \multirow{2}{*}{$\begin{array}{c}\text { Type of } \\
\text { seed } \\
\text { treatment }\end{array}$} & \multicolumn{3}{|c|}{ Type of plant treatment } \\
\cline { 2 - 4 } & Vitazim & $\begin{array}{c}\text { Fertigrain } \\
\text { Foliar }\end{array}$ & $\begin{array}{c}\text { Vitazim+Fertigrain } \\
\text { Foliar }\end{array}$ \\
\hline Poly-Feed & 3.1 & 2.7 & 4.5 \\
\hline $\begin{array}{c}\text { Plodorodiye } \\
\text { Sibiri }\end{array}$ & 2.1 & 2.4 & 4.6 \\
\hline Vitazim & 2.3 & 2.1 & 4.7 \\
\hline Agat-25K & 3.1 & 3.2 & 5.2 \\
\hline Micromak & 3.1 & 3.0 & 5.1 \\
\hline $\begin{array}{c}\text { Potassium } \\
\text { humate }\end{array}$ & 3.0 & 2.8 & 4.4 \\
\hline $\begin{array}{c}\text { Poly-Feed }+ \\
\text { Plodorodiye } \\
\text { Sibiri }+ \\
\text { Vitazim }\end{array}$ & 2.7 & 2.6 & 4.9 \\
\hline
\end{tabular}

c. Note. Synergism is the excess yield from the joint synergetic effect of preparations applied in the treatment of seeds and plants as compared with the sum of gains obtained by the separate use of the same preparations.

The greatest effect was observed in the pre-sowing treatment with Agat-25K and Micromak. Against all types of foliar treatment, the synergetic increase was 3.1-5.2 and 3.0$5.1 \mathrm{c} /$ ha, respectively. For the treatment of plants in combination with the studied seed treatment types, the mixture of VITAZIM + Fertigrain Foliar was the best; the synergetic increase ranged from 4.4 to $5.2 \mathrm{c} /$ ha.

Thus, the impacts of growth-regulating preparations on the durum wheat seeds and plants of the Zolotko variety, presented in this article, allow the following conclusions:

1. Agat-25K (1.18 seeds/plant), Vitazim (1.17 seeds/plant) and potassium humate (1.17 seeds/plant) were more effective for treating the seeds of durum wheat with a view to increasing tillering capacity.

2. The number of kernels per head increased to a greater extent when treating the seeds with Agat-25K, Micromak, Plodorodiye Sibiri, and especially with the treatment of plants with the mixture of Vitazim + Fertigrain Foliar.

3. The average weight of grains per ear increased from $1.04 \mathrm{~g}$ to 1.28 and $1.27 \mathrm{~g}$ after the seed treatment with Agat-25K and Micromak along with the treatment of plants with a Vitazim + Fertigrain Foliar mixture.

4. The thousand grain weight was greater when the seeds were treated with Agat-25K, Micromak and potassium humate together with the treatment of plants with a mixture of Vitazim + Fertigrain Foliar and made up 45.0; 44.9 and 44.85 , respectively.

5. A higher yield was obtained when Agat-25K and Micromak were used separately for treating seeds and in the mixture of Vitazim + Fertigrain Foliar for treating plants. It was 52.7 and $52.2 \mathrm{c} /$ ha, respectively.

6. The most effective synergism was observed when treating seeds with Agat-25K or Micromak jointly with treating plants with Vitazim + Fertigrain Foliar.

\section{References}

[1] N. V. Ermakova "Features of development, formation of yield and grain quality of winter durum and turgid wheat in the forest-steppe of the Central Black Earth Region," thesis for Candidate Degree in Agriculture: 06.01.09 Voronezh State Agrarian Unniversity named after K.D. Glinka. - Voronezh, 2009. pp. 26.

[2] N. V. Podlesnykh, L. M. Vlasova "Harvest and quality of grain varieties of winter durum wheat in the forest-steppe of the Central Black Earth Region," Improving the production technologies of grain, fodder and industrial crops in the Central Black Earth region: Collection of scientific publications, dedicated to the 75th anniversary of prof. V.A. Fedotova - Voronezh, 2011, pp. 49-56.

[3] V. A. Fedotov, N.V. Podlesnykh, E. A. Kupryazhkin "Synergetic effect in the joint treatment of seeds and plants of winter durum wheat," Agroindustrial complex at the turn of the century: the material of the International Scientific and Practical Conference dedicated to the 85th anniversary of the Faculty of Agricultural Engineering. - Voronezh: Voronezh State Agrarian University, 2015. Part II. pp. 169-174.

[4] R. Nandan, V. Singh, S. S Singh, "Comparative assessment of the relative proportion of weed morphology, diversity, and growth under new generation tillage and crop establishment techniques in rice-based cropping systems," Crop protection, vol.111, 2018, pp. 23-32.

[5] F. Mokrini, N. Viaene, L. Waeyenberge, "Investigation of resistance to Pratylenchus penetrans and P-thornei in international wheat lines and its durability when inoculated together with the cereal cyst nematode Heterodera avenae, using qPCR for nematode quantification," European journal of plant pathology, vol. 4, 2018, pp. 875-889.

[6] T. Schoneberg, T. Musa, Hans-Rudolf Forrer, "Infection conditions of Fusarium graminearum in barley are variety specific and different from those in wheat," European journal of plant pathology, vol. 4, 2018, pp. 975-989.

[7] P. Hellin, M. Duvivier, G. Dedeurwaerder, "Evaluation of the temporal distribution of Fusarium graminearum airborne inoculum above the wheat canopy and its relationship with Fusarium head blight and DON concentration,” European journal of plant pathology, vol. 151 (4) , 2018, pp. 1049-1064.

[8] J. Ramanauskiene, R. Semaskiene, A. Jonaviciene, "The effect of crop rotation and fungicide seed treatment on take-all in winter cereals in Lithuania," Crop protection, vol. 110 , 2018, pp. 14-20.

[9] Y. Gu, Y. Li, C. Wang, "Inter-seasonal and altitudinal inoculum dynamics for wheat stripe rust and powdery mildew epidemics in Gangu, Northwestern China," Crop protection, vol. 110 , 2018, pp. 6572.

[10] R. Loges, I. Bunne, T. Reinsch, "Forage production in rotational systems generates similar yields compared to maize monocultures but improves soil carbon stocks," European journal of agronomy, vol. 97 , 2018, pp. 11-19.

[11] S. Andert, J. Buerger, Jan-Erik Mutz, "Patterns of pre-crop glyphosate use and in-crop selective herbicide intensities in Northern Germany," European journal of agronomy, vol. 97 , 2018, pp. 20-27.

[12] E. Mansour,; Ehab S. A. Moustafa, N. Qabil, "Assessing different barley growth habits under Egyptian conditions for enhancing resilience to climate change," Field crops research, vol. 224, 2018, pp. 67-75.

[13] P. L. Mitchell, J. E. Sheehy, "Potential yield of wheat in the United Kingdom: How to reach 20 t ha(-1)," Field crops research, vol. 224, 2018, pp. 115-125.

[14] S. Vrignon-Brenas, F. Celette, A. Piquet-Pissaloux, "Intercropping strategies of white clover with organic wheat to improve the trade-off between wheat yield, protein content and the provision of ecological services by white clover," Field crops research, vol. 224, 2018, pp. 160169.

[15] S. Uddin, M. Low, S. Parvin, "Water use and growth responses of dryland wheat grown under elevated [CO2] are associated with root length in deeper, but not upper soil laye,r" Field crops research, vol. 224, 2018, pp. 170-181.

[16] J. Huzar-Novakowiski, A. E Dorrance, "Ascospore Inoculum Density and Characterization of Components of Partial Resistance to Sclerotinia 
sclerotiorum in Soybean," Plant disease, vol. 102 (7), 2018, pp. 13261333.

[17] J. A. Kolmer, , Z. Su, A. Bernardo, "Mapping and characterization of the new adult plant leaf rust resistance gene $\mathrm{Lr} 77$ derived from Santa $\mathrm{Fe}$ winter wheat," Theoretical and applied genetics, vol. 131(7), 2018, pp. 1553-1560.

[18] L. Guo, M. A. Muminov, G. Wu, "Large reductions in pesticides made possible by use of an insect-trapping lamp: a case study in a winter wheat-summer maize rotation system," Pest management science, vol. 74 (7), 2018, pp. 1728-1735.

[19] Chao Li, Cheng Li, Bingbing Wang, "Programmed cell death in wheat (Triticum aestivum L.) endosperm cells is affected by drought stress," Protoplasma, vol. 225 (4), 2018, pp. 1039-1052.
[20] GOST 10842-89. Cereals, legumes and oilseeds. Method for determining the mass of 1000 grains or $\mathrm{g} / 1000$ seeds [Text]. - Instead of GOST 10842-76; approved 1991-07-01. - Moscow: State Standard of Russia: Standards Publishing House, 1990; M: Standardinform, 2009. $4 \mathrm{p}$.

[21] GOST 13586.3-83. Corn. Acceptance rules and sampling methods [Text]. - Instead of GOST 10839-64; approved 1984-07-01. - M .: State Standard of Russia: Standardinform, 2009. - 12 p.

[22] Y. Yorozu, M. Hirano, K. Oka, and Y. Tagawa, "Electron spectroscopy studies on magneto-optical media and plastic substrate interface," IEEE Transl. J. Magn. Japan, vol. 2, pp. 740-741, August 1987 [Digests 9th Annual Conf. Magnetics Japan, p. 301, 1982]. 